\title{
Sovereignty and Natural Law in the Legal Discourse of the Ancien Régime
}

\begin{abstract}
Michel Troper*
Whenever sovereignty is defined as a supreme, absolute, unfettered and unlimited power, there is an obvious contradiction between two ideas: that states are sovereign and that they can or should be limited. Nevertheless, while many legal texts proclaim sovereignty, there are several signs that states are indeed limited by constitutional or international law. In light of this situation, some authors claim that those texts are mere proclamations and that sovereignty is an obsolete concept, while others argue that states are still sovereign and that there are no real limits, but others still try to conceive of sovereignty as limited by morality or natural law. Professor Benvenisti's remarkable theory of sovereigns as trustees of humanity is part of a very old tradition going back to the sixteenth century where sovereignty was defined as an absolute power, which is unlimited by positive law, yet based on and limited by natural law. This Article tries to show that this concept of sovereignty has emerged because of the necessity to provide a final point of imputation to the hierarchy of norms, and that the limitation by natural law was part of the original definition. Sovereignty so defined can usefully justify not only the power of kings and lawmakers but also that of courts trying to control kings and lawmakers.
\end{abstract}

\section{INTRODUCTION}

Whenever sovereignty is defined as a supreme, absolute, unfettered and unlimited power, there is an obvious contradiction between two ideas: that states are sovereign and that they can or should be limited. Nevertheless, while

* Professor emeritus University of Paris Ouest Nanterre La Défense 
a large number of legal documents, national constitutions and international treaties proclaim that states are sovereign, there are many signs that states are actually limited. Some of these limits are purely factual, but others can be found in legal documents, sometimes the same that proclaim states' sovereignty. For example, the Italian constitution simultaneously proclaims that Italy is sovereign, yet that it consents to limitations of sovereignty. ${ }^{1}$ Similarly, the U.N. Charter proclaims "the principle of the sovereign equality of all its Members" 2 and at the same time limits the use of force in international relations. ${ }^{3}$ The contrast is even sharper today if one compares the Westphalian state with the twenty-first century state after the process of globalization, the spectacular development of international law and the strengthening of international organizations, particularly organizations such as the European Union, whose law prevails over domestic law.

In light of these historical developments, some authors speak of a decline or a demise of sovereignty. They claim that the state has lost its sovereignty and that it is not necessarily a bad thing. ${ }^{4} \mathrm{~A}$ few even want to get rid of the concept altogether. To appearances, they thus evade the problem of the contradiction in the idea that states can be at the same time both sovereign and limited. According to this view, the state was sovereign in the past and thus unlimited; today it is limited and therefore not sovereign.

But other authors find it difficult to eliminate the concept of sovereignty altogether, because it is an essential part of the language of the law. Governments, national and international courts as well as international organizations constantly use it. However, they see unfettered sovereignty as dangerous and seek a way to reconcile the theory of sovereignty with the need to set it some boundaries.

There are, however, two ways to attempt such reconciliation. The first presents itself as a description of positive law. One can argue that states, because they are sovereign, can make rules and build institutions in order to set limits to themselves. Just as Ulysses had himself bound to the mast, states

1 Arts. 1-2 Costituzione [Cost.] (It.) ("Sovereignty belongs to the people and is exercised by the people in the forms and within the limits of the Constitution ...."); $i d$. art. 11 ("Italy agrees, on conditions of equality with other States, to the limitations of sovereignty that may be necessary to a world order ensuring peace and justice among the Nations.").

2 U.N. Charter art. 2, para. 1.

3 U.N. Charter art. 2, para. 4.

4 Sabino Cassese, La crisi dello Stato [The Crisis of the State] (2002) (It.); Neil MacCormick, Questioning Sovereignty: Law, State, and Nation in the European Commonwealth (1999); Neil MacCormick, Law, State, and Practical REASON (2007). 
can create constitutional courts or bind themselves by international treaties. ${ }^{5}$ The capacity to enter into international treaties is thus one of the signs of sovereignty. ${ }^{6}$ One may object that such theories are but variations on the theme of the state's self-limitation, and that self-limitations are not real limitations. States cannot be coerced to accept them or respect those limitations that they have accepted. Even when they do commit themselves by some constitutional provision to accept limitations, the constituent power remains sovereign and can always make exceptions to a principle.

The second way is normative. One can justify the moral necessity to limit the power of states and then suggest the creation or strengthening of some rules or institutions that would make those limitations effective. This seems to be the path followed by Professor Benvenisti. In an important contribution to the theme, he writes that states should be considered "trustees of humanity." $\mathrm{He}$, thus inevitably encounters the puzzle of a limited sovereignty, because a trustee does not act or decide in his own right (suo jure). A trustee must have been empowered by a rule or deputed by some entity, his powers are not unlimited, and he can be held accountable. Thus, if a state were a trustee in the full sense of the word, it could not be considered sovereign. But Professor Benvenisti does not endorse the thesis of the demise of sovereignty, on neither a descriptive nor normative level. He believes that "sovereignty must not be condemned but, instead, celebrated, as long as it incorporates some responsibilities toward the rest of humanity." ${ }^{\text {"T }}$ This clearly implies a redefinition of sovereign, a redefinition that incorporates the idea of some limits.

But if sovereignty is thus both preserved and limited, the paradox has been solved only apparently. There is obviously no contradiction between sovereignty defined as a power that can be limited and the thesis that it should be. However, the original contradiction is between this thesis and a power defined as without limits. And that contradiction unfortunately remains.

Therefore, one cannot avoid the paradox either by describing positive law or by suggesting new developments of international law; only one way remains open: to describe the law is not to describe some metaphysical

5 Jon Elster, Ulysses and the Sirens: Studies in Rationality and IrRationality (1979).

6 Jean Combacau, La souveraineté internationale de l'État dans la jurisprudence $d u$ Conseil constitutionnel français [International Sovereignty of the State in the Jurisprudence of the French Constitutional Council], 9 CAHIERS DU CONSEIL CONSTitutionnel 113 (2000) (citing the case of the S.S. Wimbledon, 1923.08.17: Judgment No.1 (1923) P.C.I.J. (ser. A) No. 1).

7 Eyal Benvenisti, Sovereigns as Trustees of Humanity: On the Accountability of States to Foreign Stakeholders, 107 Am. J. INT'L L. 295, 300 (2013).

$8 \quad$ Id. at 301. 
entities, such as sovereignty, but to describe rules. Rules can be described not only as to their form, but also as to their content: what they command, prohibit or authorize, what concepts they use to formulate these commands or prohibitions, and what justifications are provided for using these concepts. This description does not aim at solving the paradox, but at showing why, in spite of all its contradiction, a doctrine of sovereignty is inevitable and becomes a key element in the language of the law. The circumstance that legal conceptions are sometimes self-contradictory does not make them less effective. Some theories are necessary and the legal system cannot work without them. This is precisely what emerges from Professor Benvenisti's attempt: that it is logically impossible to reconcile the concept of sovereignty with the idea of limits to the power of the state, and yet impossible to talk about the state without using this concept and at the same time difficult to avoid looking for some basis for it. Since such a basis cannot be found within the legal system, it has to be found in some metalegal system, such as natural law or morality. Professor Benvenisti hence discusses "normative bases for considering sovereigns as global trustees" and defines those bases as moral. ${ }^{9}$

Thus, while we cannot describe the essence of sovereignty or answer the question whether it is limited or unlimited, we can describe the language of the law and see that at least some of those who have written on sovereignty have been constrained to consider it as both legally unlimited and based on and limited by metalegal norms.

Since the language of sovereignty is not universal, but emerged in the context of sixteenth century Western Europe in close association with the development of the modern state, we can ask what the word meant for the men who used it in that period and whether they thought of sovereignty as limited or unlimited. One traditional way of dealing with that question is through the history of ideas, looking at Bodin, Hobbes, Puffendorf and others. This has been done with considerable talent and success. According to one of its major exponents, this method aims at identifying "the views of specific writers about the concept of the state [by examining] the precise circumstances in which they invoke and discuss the term state." 10 The circumstances that modern historians of ideas have in mind are political circumstances. They include the political debates in which canonical authors have participated. The history of political theory thus appears to be a history of ideologies. ${ }^{11}$

$9 \quad I d$.

10 Quentin Skinner, The Sovereign State: a Genealogy, in Sovereignty in Fragments: The Past, Present, and Future of a Contested Concept 26 (Hent Kalmo \& Quentin Skinner eds., 2010).

11 Quentin Skinner, Surveying the Foundations: A Retrospect and Reassessment, 
One might, however, try to extend this method and view such concepts as state or sovereignty as elements not only of political but also of legal theories. This could help answer two questions. First, if these concepts were really engineered as responses to precise political circumstances, one would expect that from different circumstances would see the emergence of different concepts. Why then did authors like Bodin, Puffendorf, Hobbes, or Rousseau, writing at very different moments under very different political circumstances, use similar concepts? Second, why was it necessary for legal actors, such as kings or courts, to make such intensive and consistent use of these concepts in political contexts that were so different? Naturally, kings who wished to proclaim their supremacy could find the concept of sovereignty useful, but why courts?

One possible explanation could be that the concept of the king's sovereignty was rendered necessary and emerged with the structuration of the modern state as a hierarchy of norms in the sixteenth and seventeenth centuries. In Part I, I will try to test that hypothesis. In Part II, as a second step, I will try to show that lawyers had little choice but to conceive of a sovereign both absolute and limited. What is striking is that, in the theory of sovereignty that emerged from the hierarchy of norms at the beginning of the modern era, the sovereign was at the same time unbound by law and bound by natural law, the two of which obviously have a different content but not a different function from the normative bases listed by Professor Benvenisti.

\section{Sovereignty as a Product of the Hierarchy of Norms}

\section{A. The Modern State as a Specific Form of Political Power}

There is an ongoing debate among legal historians about the emergence of the state. Some see it "in the transition from the nomadic subsistence of hunter-gatherers to more agrarian societies, characterized, increasingly, by organized agriculture," 12 while others date it from the sixteenth century and

in Rethinking the Foundations of Modern Political Thought 236, 242 (Annabel Brett, James Tully \& Holly Hamilton-Bleakley eds., 2006) (“[T]he most illuminating way of writing even about Hobbes's political theory may be to treat it essentially as a political act, then perhaps this may be the most illuminating way of writing about political theory tout court.").

12 Colin Hay \& Michael Lister, Introduction: Theories of the State, in The StATE: Theories And Issues 1, 5 (Colin Hay, Michael Lister \& David Marsh eds., 2006). 
others still at various periods in the Middle Ages. ${ }^{13}$ They obviously rely on different definitions of the state. The former will be satisfied with the presence of some relatively centralized political institutions or a distinct territory, and will find that there is a state in most human societies other than primitive groups. ${ }^{14}$ The latter would want a definition not of the state in general, but of the modern state, and use other criteria such as a legislative power or the fact that the government is defined as sovereign, and there is no agreement as to what counts as "legislative power" or "sovereign." Take legislation: for some, it is enough that the French King could and did indeed make some general rules already in the twelfth century, but others will stress that he was far from having a monopoly on the production of these rules; that these laws, unlike modern statutes, did not deal with every possible human conduct; and that the King's legislative power did not extend to private law, which remained regulated by other independent sources, such as custom, ecclesiastic law or the jurisprudence of the courts. Thus, depending on the definition of the state that they choose, historians date its existence from the beginning of human societies, from the late Middle Ages, or from the sixteenth century.

As for "sovereignty," although the word was not used before the sixteenth century, we find some occurrences of "sovereign" in the Middle Ages and a few other terms, such as maiestas, potestas absoluta, summa potestas, or imperium, have been considered by some historians as conveying at least part of that meaning. ${ }^{15}$ But how can we be sure that the part of the meaning that these terms fail to convey is not precisely what is so important about sovereignty? If sovereignty is a defining feature of the modern state and plays an essential role in the system, this must be related to the specificity of the system itself. It is not enough to say that the state is a political system with a sovereign, which is different from other forms of political organization without a sovereign.

13 See, e.g., Bernard Guenée, Espace et État dans la France du bas Moyen Âge [Space and State in the France of the Late Middle Ages], 23 AnNALES: Économies, SociÉTÉs, Civilisations 744 (1968) (Fr.).

14 See Pierre Clasteres, Society Against the State: Essays in Political Anthropology (1989).

15 M.J Wilks, The Problem of Sovereignty in the Later Middle Ages 152 (1963); Marcel David, La souveraineté du peuple [Sovereignty of the People] (1996). Contra Helmut Quaritsch, Souveränität: Entstehung und Entwicklung des Begriffs in Frankreich und Deutschland von 13 Jh. bis 1806 [Sovereignty: Emergence and Development of the Concept in France and Germany from the Tirteenth Century to 1806] 34 (1986) (Gr.) ("Uber die Unmögligkeit 'mitttelaterlicher' Souveränität." ["On the impossibility of a medieval sovereignty.']). 
We must thus use a definition of the state independent of that particular character, and we may start from Max Weber's famous definition: "an entity, which successfully claims a monopoly on the legitimate use of violence."16 Kelsen rightly stresses that this monopoly cannot be a de facto monopoly, because there are many acts of violence that are not committed by the state; it is a monopoly on the legitimate use of violence. But the word "legitimate" does not imply that the use of violence by the state is just or in accordance with certain fundamental values. It means that acts of violence are performed according to legal rules. On the other hand, the state is an abstraction and thus incapable of exercising violence. Only human beings can exercise violence, but the acts accomplished by some individuals are imputed to the state and this is only made possible by way of legal rules that prescribe which actions by which individuals will be imputed to the state. ${ }^{17}$

Thus, the state is simply that entity that acts by means of legal rules. These rules serve to appoint some individuals whose actions will be the state's, and they are considered legal rules when they have been produced in accordance with higher rules. Weber's rational legitimacy functions when there is a hierarchy of norms characteristic of a legal system.

Kelsen concludes that the state and the law are two words for one and the same phenomenon. This view is not at odds with Weber's. On the contrary, it supplements it. ${ }^{18}$ Kelsen does not deny that the state is law instead of politics or instead of force. He merely stresses that in the state, political power is exercised by means of rules. As he famously wrote on several occasions:

Whoever looks for an answer to the eternal question of what stands behind the positive law will never find, I fear, either an absolute metaphysical truth nor the absolute justice of natural law. Who lifts the veil and does not shut his eyes will find staring at him the hideous Gorgon head of power.... ${ }^{19}$

16 Max Weber, Politik als Beruf [Politics as a Vocation], Lecture at Munich university (1918), printed in Max Weber, Gesammelte politische Schriften [Collected POLITICAL WorKs] 396 (1921), available at http://anthropos-lab.net/wp/wp-content/ uploads/2011/12/Weber-Politics-as-a-Vocation.pdf.

17 HANS Kelsen, DER SOZIOLOGISCHE UND DER JURISTISCHE STAATSBEGRIFF: KRITISCHE Untersuchungen deS Verhältnisses VON STAAT Und ReCht [The Sociological and the Legal Concept of the State: Critical Investigation on the Relation Between State and Law] (1928).

18 Michel Troper, Le droit et la nécessité [LaW and Necessity] 61-76 (2011) (Fr.).

19 Metall R., Hans Kelsen, Sein Leben und Werk [Hans Kelsen, His Life and Work] 30 (1969) (Gr.). Kelsen had already used the image of the Gorgona in 
Exercising political power by means of a legal system structured in a hierarchy brings several advantages. The highest authority can at the same time empower lower authorities to make decisions, and retain control over the content of these decisions by enacting general rules that the lower authorities are bound to apply. As for the lowest authorities, their decisions will be rationally justified since they will appear as mere applications of higher norms, though they will retain some discretion. This is both because the empowering rules explicitly grant it and also because most of these authorities, particularly law courts, can always interpret the words of the rules that they are applying.

Kelsen's thesis of the unity of law and state nevertheless faces a difficulty regarding the common use of the word "state" to refer not to the national legal order but to a group of centralized authorities, differentiated from civil society and from local authorities. In that sense, the state is obviously not identical with the legal order. He is thus constrained to make a capital distinction between the state lato sensu (the legal order) and the state stricto sensu (the set of centralized authorities) and writes that the latter concept presupposes the former. By this, he means that one cannot think of the state stricto sensu without conceiving it as the set of those organs that produce the norms that are at the top of the entire legal order, i.e., at the top of the state lato sensu. In other words, the legal system, structured in a hierarchy of norms, presupposes a state lato sensu. That state is then personified, conceived as an entity distinct from the individuals who hold an office and endowed with certain qualities, such as unity, continuity and, above all, sovereignty.

Although Kelsen's theory is not a historical one, it is of great importance for the problem of the date of the emergence of the state: the state appeared with the hierarchy of norms, i.e., in the sixteenth century. In the Middle Ages, there was no hierarchy in the modern sense, where a human act of will has the meaning of a legal norm when its author has been empowered by a higher norm and all norms are part of a single system. Such a hierarchy took shape gradually between the fifteenth and seventeenth centuries, when the King succeeded in subordinating all existing sources of law, such as custom or judge-made law, under the royal legislation; and when lower authorities, particularly courts, justified their own decisions by claiming that they were applying higher laws.

The state thus appears as a system of legitimation in two different ways. First, the hierarchy of norms provides a rational justification for the decisions of the various subordinate authorities, which can argue that they are applying

3 Veröffentlichungen derVereinigung der Deutschen StaAtsrechtslehrer [Publications of the Association of German Teachers of Constitutional Law] 54-55 (1927) (Gr.) (translated by the author). 
higher rules. Second, the authorities use a type of political discourse that is specific to this form of political power. It is made up of a number of principles that can be said to be constitutive, because we recognize that a political system is a state when power is justified by invoking some specific principles such as sovereignty, representation, and distinctions between office and office holder, public and private law, state and civil society, and personality and continuity of the state. The most important of these constitutive principles is sovereignty, so that the emergence of the principle of sovereignty is rightly considered the sign of the emergence of the state. It emerged in the sixteenth century as a consequence of the hierarchy of norms. ${ }^{20}$

\section{B. The Hierarchy of Norms and Sovereignty}

The word "sovereignty," as it is used in the modern state, has been defined by the foremost modern French legal theorist Carré de Malberg, who broke up the notion of sovereignty into three concepts:

In the original sense, the word "sovereignty" refers to the supreme character of the State's power. In a second sense, it refers to the whole range of the powers included in the State's authority and it is therefore synonymous with that authority. Thirdly, it is used to characterize the position occupied within the State by the highest organ of the State's authority and in that sense, sovereignty is the same thing as the power of that organ. ${ }^{21}$

This distinction helps to clarify the way we use the term "sovereignty" and the various functions that the notion performs.

One issue is whether it is possible to divide sovereignty. On the basis of Carré de Malberg's distinction, it is easy to see that sovereignty in the third sense, the quality of the highest organ of the state, is indeed indivisible, because as soon as one divides it between several organs, none is the highest. ${ }^{22}$ On the other hand, if sovereignty in the second sense is the range of powers

20 Michel Troper, The Hierarchy of Norms and the Emergence of the State (The Straus Ins. for the Advanced Studies of Law \& Justice, Straus Working Paper No. 06/12, 2012), available at http://www.law.nyu.edu/sites/default/files/siwp/ WP6Troper.pdf.

21 Raymond Carré de Malberg, Contribution à la théorie générale de l'Etat; SPÉCIALEMENT D’APRÈS LES DONNÉES FOURNIES PAR LE DROIT CONSTITUTIONNEL FRANÇAIS [A Contribution to the General Theory of the State, Particularly from Data Drawn from French Constitutional LaW] 79 (Dalloz 2003) (1920) (translated by the author).

22 However, several organs could exercise sovereignty jointly. 
that can be exercised by the state, it is perfectly divisible. It is even possible to divide them by their subject matters (the power to wage war, to control a currency, to render justice, etc.), as Samuel Puffendorf did with the "potential parts of supreme sovereignty, ${ }^{\prime 23}$ or by the type of legal acts that are necessary to exercise them (like legislation, execution and adjudication). Separation of powers is precisely a division of sovereignty in this sense.

In the same way, these distinctions help us to understand why some sentences using the concept of sovereignty, which seem incompatible or contradictory, can nevertheless be simultaneously true. Thus, at the time of Carré de Malberg, during the French Third Republic, it was possible to answer the question "who is the sovereign?" by any one of three sentences: "the French State is the sovereign," "the French Parliament is the sovereign," and "legislation is a sovereign power." In the first sentence, sovereignty refers to the supreme character of the state's power, which enables it to act on the international level and interfere with other sovereigns, or to dominate the church or any other institution; in the second sentence, sovereignty is a quality of an organ of the state; and in the third sentence, it is one of the powers that the state may exercise.

However, Carré de Malberg's distinction does not provide a sufficient account of some sentences that we find in constitutional and political discourse. Take, for example, "the sovereign is the French people," or "sovereignty belongs to the people." ${ }^{24}$ Such a sentence obviously does not mean that the French people is the state and effectively acts on an international level, nor that it exercises a power of domination, and certainly not that the people alone can really exercise a range of powers. These propositions do not refer to any reality and they are only used to justify other sentences. For example, in French legal discourse, "sovereignty belongs to the people" was used during the Third Republic to justify "Parliament is sovereign" or "the law is sovereign." It meant that Parliament exercised a sovereignty that was not its own, but belonged to the people and was exercised in the name of the people, or that statutes were presumed to express the general will, i.e., the will of the sovereign, and were therefore supreme. In this context, when imputed to the people, the word "sovereignty" is thus used in a fourth sense: it refers to the quality of a being in whose name some power, in any one of the first three senses, is exercised. Indeed, the theory of sovereignty generally implies a distinction between the essence and the exercise of sovereignty.

Because of the hierarchy of norms, what is imputed to a sovereign is not only legislation or decisions in international affairs, but also every single

23 Samuel Pufendorf, On the Laws of Nature and of Nations (1672).

241958 Const. 3 (Fr.). 
act presumed to have been performed by virtue of a delegation. This is why, for example, justice is rendered in European countries "in the name of" the French, Italian or German people, as it was before "in the name of the king." To Carré de Malberg's three concepts, we must therefore add a fourth: the doctrine of sovereignty is a principle of imputation. A sovereign in that fourth sense is the entity presumed to possess the essence of a sovereignty that is exercised by others in its name and thus to be the author, direct or indirect, of every single norm in the system.

We thus have four different concepts of sovereignty, and we can see that in the Middle Ages there might have been a sovereign in the first and third senses, but certainly not in the second and fourth. Only after the sixteenth century do we find sovereignty in all four senses of the word. What is different from the Middle Ages, regarding the second sense, is the type and the range of powers that the King can exercise: while he could not legislate in matters related to private law up to the sixteenth century, he then started making laws on marriage and even on ecclesiastical matters. As for sovereignty in the fourth sense, imputation, we also find it only in the modern state. Because of the unity of the legal system, every single norm belonging to that system has either been produced directly by the will of the King - he wrote at the end of the laws "car tel est notre plaisir" ("for this is our pleasure") — or has been produced by the will of an authority empowered by the King, in the name of the King.

The emergence of the concept of sovereignty was directly related to the hierarchy of norms, because the King was the only authority in the system whose power could not be justified by referring to an empowering rule, because there was no such higher rule. The only possible justification was therefore to presuppose that his power was of a different nature and had a godlike quality.

\section{A Sovereign Both Absolute And Limited}

The sovereign can thus be defined as the supreme point of imputation. This implies that there is no higher authority that could have empowered him and simultaneously limited his rights. ${ }^{25}$ In this sense, the King sovereign was truly absolute. However absolutus only meant the absence of legal limits and nothing else. Legal limits were limits in positive law. Thus, sovereignty

25 Jean Bodin, Six Books of the Commonwealth (Les Six livres de la République) bk. I, ch. VIII (M.J. Tooley trans., Basil Blackwell Oxford 1955) (1579), available at http://www.yorku.ca/comninel/courses/3020pdf/six_books.pdf ("Sovereign power given to a prince charged with conditions is neither properly sovereign, nor absolute.") (translated by the author). 
did not preclude limits other than legal limits, strictly speaking. However, these other limits were not real and effective limits. On the contrary, this character of the King's power being limited by natural law and by natural law only was part of the definition of sovereignty. ${ }^{26}$ As Gérard Mairet writes, "the doctrine that the prince is subject to natural and divine law, far from limiting his power helps on the contrary to justify that it is without limits."27 A reference to natural law can serve several functions. It helps to distinguish between monarchy and tyranny or despotism; it provides a metajuridical basis for the power of the sovereign; and it allows for some form of judicial review of the sovereign's actions.

\section{A. The Distinction Between Monarchy and Tyranny or Despotism}

Bodin knew that the word "tyrant" referred in Ancient Greece to a mode of accession to power, a conquest without the consent of the subjects, but not to a mode of governance. ${ }^{28}$ The tyrant could, after all, exercise power fairly. ${ }^{29}$ But Bodin also knew that in his time it had become a synonym for arbitrary and evil power, independently of the means by which that power had been gained. According to some theories, the killing of the tyrant was justified. ${ }^{30}$

If monarchy were defined simply as a form of government where sovereignty is vested in one man, who is legibus solutus (not bound by the laws), tyranny would be the same as monarchy and the King could be called a tyrant. It was

$26 I d$. ("If we insist however that absolute power means exemption from all law whatsoever, there is no prince in the world who can be regarded as sovereign, since all the princes of the earth are subject to the laws of God and of nature, and even to certain human laws common to all nations.") (translated by the author).

27 Gérard Mairet, Introduction to Bodin, Les Six livres de la République (Paris: Librairie générale française 1993).

28 Bodin, supra note 25, bk. 1, ch. VIII:

If a sovereign magistrate is given office for one year, or for any other predetermined period, and continues to exercise the authority bestowed on him after the conclusion of his term, he does so either by consent or by force and violence. If he does so by force, it is manifest tyranny. The tyrant is a true sovereign for all that.

29 Id. bk. II, ch. IV:

The word tyrant, which in Greek was originally an honourable term, merely signified the prince who had come into power without the goodwill of his subjects, and from being an equal had raised himself to be their master. Such a one, even though he proved a wise and just prince, was called a tyrant.

30 Mario Turchetti, Tyrannie et tyrannicide de L'AntiQuité À nos Jours [Tyranny and Tyrannicide from Antiquity to the Present] (2001) (Fr.). 
therefore crucial to distinguish between the two, and the only way to do so was to say, as Bodin did, that whereas the King respects the laws of nature, the tyrant violates them. ${ }^{31}$

Montesquieu faced the same difficulty and solved it in exactly the same way. It is well known that he substitutes a new typology for the traditional one. Instead of a distinction between monarchy, aristocracy and democracy, based simply on the number of power holders (one, a few, or all), he distinguishes between monarchy, despotism, a synonym for tyranny, and republic. ${ }^{32}$ Monarchy and despotism have a common character: in both cases, power is vested in one person, but in a monarchy the king exercises it according or by means of fixed and established laws, while in a despotism, power is also exercised by one man, but without laws, i.e., "according to the prince's whims." It follows that the principles or mainsprings of both systems are completely different: while the principle of monarchy is honor, the principle of despotism is fear and that of the republic virtue. They also have different ends or objects, which each of them will tend to produce by virtue of its nature: for monarchy, it is the glory of the prince and the state; for despotism, his pleasures. ${ }^{33}$

These fixed and established laws, which serve as a criterion to distinguish monarchy from despotism, are of two kinds: first, there are general rules that

31 Bodin, supra note 25, bk. II, ch. II:

Royal, or legitimate, monarchy is one in which the subject obeys the laws of the prince, the prince in his turn the prince the laws of God .... Tyrannical monarchy is one in which the laws of nature are set at naught, free subjects oppressed as if they were slaves, and their property treated as if it belonged to the tyrant.

See also id. bk. II, ch. IV ("The most notable distinction between the king and the tyrant is that the king conforms to the laws of nature and the tyrant tramples them underfoot.").

32 Montesquieu, The Sirit of the Laws bk. II, ch. I (1748), available at http://oll. libertyfund.org/titles/837:

There are three species of government; republican, monarchical, and despotic. In order to discover their nature, it is sufficient to recollect the common notion, which supposes three definitions, or rather three facts: That a republican government is that in which the body or only a part of the people is possessed of the supreme power: monarchy, that in which a single person governs by fixed and established laws: a despotic government, that in which a single person directs everything by his own will and caprice.

33 Id. bk. XI, ch. V ("Of the End or View of different Governments. Though all governments have the same general end, which is that of preservation, yet each has another particular object. Increase of dominion was the object of Rome; war, that of Sparta; religion, that of the Jewish laws; commerce, that of Marseilles ....”). 
the king enacts, applies equally, and does not change according to particular circumstances or to the personalities of his subjects. He exercises his powers "par des lois," (by means of laws), by means of general rules. But there are also rules that the King does not enact and that moreover it is not in his power to derogate. ${ }^{34}$ They are the fundamental laws of the realm, for example the laws that regulate succession to the throne or the laws that prohibit the alienation of the royal domain. And these laws were considered natural and divine. ${ }^{35}$

There is therefore no contradiction between the idea that the King's power is absolute and this other idea that his power is limited by law. Bodin himself wrote that if sovereignty meant that one was above the laws, then no prince is truly sovereign because every prince is bound by divine and natural law. ${ }^{36}$ Being absolute is not exercising a power with no limits, but exercising a power limited only by natural or divine laws, ${ }^{37}$ which does not necessarily mean an effective limitation, but, as we shall see, does not preclude it.

\section{B. The Metajuridical Basis for the Power of the Sovereign}

Why is the sovereign, sovereign? The reason cannot be that he has been empowered by a higher authority, since he himself is the highest authority. On the other hand, one could no longer justify the King's power by a personal and mystical quality that he alone possessed.

In the Middle Ages that quality came from the coronation in Reims. Following a rite similar to that used for the sacrament of bishops, the King was anointed with sacred oil from the "holy ampoule," a small glass bottle, which according to the legend had been brought by a dove for the sacre of

34 Louis XV, Flagellation speech (Mar. 3, 1766) (declaring that sovereign power resided in him alone and that the courts' existence and authority only derived from him, but also that, happily, he was powerless ("dans l'heureuse impuissance") to change the fundamental laws of the realm).

35 Marie-France Renoux-Zagamé, Du droit de Dieu au droit de l'homme [From the Law of God to the Rights of Man] 317-19 (2003) (Fr.).

36 Kenneth Pennington, The Prince and the Law, 1200-1600: Sovereignty and Rights in the Western Legal Tradition 276-77 (1993).

37 Bodin, supra note 25, bk. I, ch. VIII ("This power is absolute and sovereign, because it has no other limit than what the law of God and of nature commands.") (translated by the author). This definition of absolute power, as that which has no other limit than natural or divine law, has been reproduced over and over. See, e.g., Cardin Le Bret, De La Souveraineté Du Roy [On the King's Sovereignty] bk. I, ch. II ("Que c'est que la souveraineté et que sa première marque est de ne dépendre que de Dieu seul." ["On what is sovereignty and that its first mark is to depend on God alone.”]). 
Clovis in $496,{ }^{38}$ and it was that sacrament that gave him his charismatic quality. Only after having been anointed was he able to perform miracles and heal the sick suffering from écrouelles, a form of tuberculosis affecting the skin or scrofula, simply by touching them. His power was thus not unlike that of other authorities, which also held it not because of a delegation, but suo jure, because of their own specific nature.

However, when there is a hierarchy of norms and every single authority exercises powers delegated by a higher authority by means of rules, the King cannot derive his power from his specific nature. This is the reason why Bodin stresses that the prince is not sovereign because of the coronation, but by right, and that he is sovereign even before having been crowned. ${ }^{39}$ On the other hand, however, this right cannot result from a delegation from a higher human authority, since there isn't one. Thus, the only possible basis for his power is divine and natural law.

Indeed, both historically and logically, the fundamental laws of the realm had to be considered as divine and natural law. In France, the most important of these laws was the Salic law, which prescribed that the eldest son became King after his father and that women could neither ascend to the throne nor transmit the right of succession. At the end of the sixteenth century, Henry of Navarra, who was a Protestant and had been excommunicated, was next in line to the throne according to the Salic law. There was thus a conflict between canon law and the Salic law. As Marie-France Renoux-Zagamé has convincingly shown, traditional natural and divine law was not an adequate basis for the King's power, because it was the basis for the institution of political power in the abstract, not for the power of one man in particular. As a consequence, in order to find an argument in favor of the latter, one was forced to argue that the Salic law was the direct expression of God's will. God must be considered the author of all the subsequent laws and subjects were therefore under an absolute obligation to obey the King..$^{40}$ Another important consequence was that the Salic law although divine, being specific to France

38 Marc Bloch, The Royal Touch: Monarchy and Miracles in France and England (1990).

39 Bodin, supra note 25, bk. I, ch. 9 ("Combien que le Roi ne laisse pas d'être Roi sans le couronnement, ni consécration: qui ne sont point de l'essence de la souveraineté." ["The King is no less king for not having been crowned or consecrated, for coronation and consecration are not part of the essence of sovereignty."']).

40 Renoux-Zagamé, supra note 35, at 317-20; Marie-France Renoux-Zagamé, Du juge prêtre au roi-idole. Droit divin et constitution de l'Etat dans la pensée juridique française à l'aube des Temps Modernes [From the Judge as Pries to the King as Idol, Divine Right and Constitution of the State in French Legal 
and outside canon law, escaped interpretation by the Church. The divine right of Kings was thus a continuation of the dynamic hierarchy of norms. The law is not a natural quality of being and norms are only recognized as binding because they are the expression of the will of an individual who has been empowered by a superior will. Natural law must thus be considered only as God's will.

Power, then, is not an expression of a personal quality of its holder. Just as courts and officers were empowered by the expression of the King's will, the King was empowered by God's will. His power did not result from his own divine nature, but only from delegation. When King James famously said that "kings are justly called gods" $"$ he did not refer to their personality or to some mystical quality, but to the nature of their power: "they exercise a manner or resemblance of Divine power." He only mentioned coronation because of the oath and not because of anointment. In reality, the basis for sovereign power had become secular. ${ }^{42}$

The change that had occurred became manifest when the King ceased to claim this charismatic quality in official circumstances. In the eighteenth century he still touched the sick to cure them of scrofula, but using completely different words: instead of saying, "the king touches you, God heals you," Louis XV said, "the king touches you, may God heal you."43 He thus acknowledged the loss of his magical power. All he could do was pray to God.

However, although the sovereign finds in natural law a basis for his power, he does not encounter any limits. On the contrary, the divine right of Kings is just another manifestation of absolutism. ${ }^{44}$ At least until the courts attempted to transform the virtual supremacy of natural law into a real supremacy by exercising judicial review.

\section{The Basis for Judicial Review}

There is a general tendency of courts in various legal systems to seek an extension of their own power and to justify the exercise of control over

Thought at the Dawn of the Modern Times], in LE DROIT ENTRE LAÏCISATION ET NÉO-SACRALISATION 143 (Jean-Louis Thireau ed., 1997).

41 James I, Speech Before Parliament (Mar. 21, 1609), printed in The Political Works OF JAMES I, at 307-08, 528-31 (1616).

42 Mairet, supra note 27.

43 Roland Mousnier, The Institutions of France Under the Absolute Monarchy, 1598-1789, at 655 (1979).

44 Fanny Cosandey \& Robert Descimon, L'absolutisme En France: Histoire Et Historiographie [Absolutism in France: History and Historiography] (2002) (Fr.). 
legal norms by claiming that they are merely applying higher norms, even when they have not been expressly authorized to do so and when there is no certainty about the existence and status of those higher norms. The most famous example of this tendency is the American Supreme Court's decision in Marbury v. Madison: the Chief Justice, John Marshall, wrote that since the Constitution was superior to ordinary laws, the courts ought to refuse to enforce laws contrary to the Constitution. ${ }^{45}$

However, the basis of the reasoning, the idea that the constitution is superior to ordinary laws, is far from self-evident. "Superiority of the constitution" can have several meanings. It can mean first that the constitution has empowered a legislative authority and established the form and procedures by which ordinary laws can be produced. Every constitution is of course superior in that sense. But it can also mean that in case of a conflict between the content of the constitution and that of an ordinary statute, the latter ought to be regarded as invalid and courts ought to refuse to enforce it. Thus, the power of the courts to disapply an unconstitutional statute does not follow logically from a general superiority of the constitution, but only from its superiority in the latter sense. Marshall's reasoning was perfectly circular, and he merely deduced the courts' power to refuse to enforce an unconstitutional law from the idea that the courts had that power, but not every constitution is superior in that second sense. In fact, if the American Constitution is indeed superior, this is because of Marbury. Marbury is not a consequence of the superiority of the Constitution. It is the superiority of the Constitution that is a consequence of Marbury. It is a creation of the court. ${ }^{46}$

Many other courts have used similar reasoning to justify the exercise of judicial review and have similarly established the superiority of some norms over others. In 1971, the French Constitutional Council, which has since become the Constitutional Court, decided that the Declaration of the Rights of Man and the Citizen of 1789 had constitutional value. ${ }^{47}$ Similarly, in 1980, the Supreme Court of India ruled that it had the power to review constitutional amendments and invalidate those that conflicted with some

45 Marbury v. Madison, 5 U.S. 137 (1803).

46 Michel Troper, Marshall, Kelsen, Barak and the Constitutionalist Fallacy, 3 INT'L J. CONST. L. 24 (2005).

47 Conseil constitutionnel [CC] [Constitutional Court] decision No. 71-44DC, July 16, 1971 (Fr.). An English translation of the Declaration of the Rights of Man and the Citizen of 1789 is available in Declaration of human and Civic Rights of 26 August 1789, Constitutional Council of the French Republic, http://www.conseil-constitutionnel.fr/conseil-constitutionnel/english/constitution/ declaration-of-human-and-civic-rights-of-26-august-1789.105305.html (last visited May 23, 2015). 
unwritten superconstitutional principles. ${ }^{48}$ In 1995, even though Israel does not have a written constitution, the Supreme Court decided that it could review statutes against some fundamental laws that, taken together, should be regarded as forming the constitution of Israel. ${ }^{49}$ In all these cases, the courts have spontaneously created the supremacy of some norms over ordinary legislation, but some pretended to have discovered those norms in the written constitution, while others have discovered them — and their superiority — in unwritten principle.

This was precisely the kind of attitude of the Parlements, the supreme courts of the land before the French Revolution. The laws enacted by the King were sent to these courts to be registered. However, the Parlements claimed the right to refuse to register the King's laws when they conflicted with the fundamental laws of the realm. In their view, though, the fundamental laws extended far beyond the Salic law and included natural law, tradition and the principles of reason. In reality, they aimed at - and to a certain extent succeeded in - sharing the legislative power with the King. ${ }^{50}$

The Parlements' participation in the legislative power resulted from their decision to consider fundamental laws superior to the King. They had indeed created a new level in the hierarchy of norms above the King and they had complete discretion to decide which principles counted as fundamental norms and to interpret their content. They could thus avoid admitting that they exercised that power in resistance to the King's will, by claiming that they reviewed the King's laws not for policy reasons but only for their conformity with higher norms. ${ }^{51}$

They had to resort to natural law for several reasons. The first and most obvious was that there was no positive law above the King. Another and equally important reason was that the idea that the King's power could be checked was difficult to reconcile with the doctrine that the King was sovereign. Such reconciliation could be attempted by claiming that since the Parlements' power resulted from a delegation by the sovereign, when they exercised a check on the King, they still acted in the name of the sovereign. ${ }^{52}$

48 Minerva Mills Ltd. v. Union of India, (1980) RD-SC 141 (India).

49 CA 6821/93 United Mizrahi Bank Ltd. v. Migdal Village, 49(4) PD 221 [1995] (Isr.).

50 Sarah Hanley, The 'Lit de Justice' of the Kings of France: Constitutional Ideology in Legend, Ritual, and Discourse (1983).

51 Fransisco Di Donato, La rinascita dello Stato — Dal conflitto agistraturapolitica alla civilizzazione istituzionale europea [The Revival of the State - From the Conflict Between the Judiciary and Politics to the Institutional Civilization of Europe] ch. V (2010) (It.).

52 Francesco Di Donato, L'ideologia dei robins nella francia dei lumi. 
When they refused to register a law, they weren't opposing the King's will, because such a law only expressed the King's apparent will - the will of the individual who happened to be on the throne - and not the real will of the King as an institution. The real will was thus expressed by the Parlement, but imputed to the sovereign King. ${ }^{53}$

As mentioned above, it is submission to natural law that characterizes the sovereign and distinguishes monarchy from tyranny. In a monarchy, according to the Parlements, the King acts not according to his will, but according to what he ought to will, i.e., according to natural law. Thus, by correcting the laws and forcing the King to act according to natural law, the Parlements could claim to make monarchy true to its essence. Natural law was the tool that enabled them to review the King's law, to take part in the legislative power, and to complete the process of imputation.

\section{Conclusion}

What this story tells us is that sovereignty and natural law can be reconciled and indeed have been reconciled in the past. This happened because the hierarchy of norms was the main factor in the emergence of the notion of sovereignty and fueled the need to find both a basis for and limits to the power of the sovereign. But, although the limits found in natural law were not real and effective limits, the courts were always able to use the theory of sovereignty and the theory of natural law, taken together, in order to exercise some form of control over Kings.

Obviously, the reconciliation is not a logical one. It remains impossible to conceive the state's power as both absolute and limited. But the logical contradiction allows for a redefinition of absolute power as one that is subject only to natural law or to moral principles. Such a definition has several consequences. Not only does it provide a legitimacy to the state's power, but it also allows courts to claim that the limits they built against political power are not against the sovereign but in the name of the sovereign.

COSTITUZIONALISMO E ASSOLUTISMO NELL'ESPERIENZA POLITICO-ISTOTUZIONALE DELLA magistratura di antico Regime (1715-1788) [The Ideology of Judges in the France of the Enlightenment: Constitutionalism and Absolutism in the Political and Institutional Experience of the Judiciary in the 'Ancien Regime' (1715-1788)] (2003) (It.); Francesco Di Donato, La hiérarchie des normes dans l'ordre juridique, social et institutionnel de l'Ancien Régime [The Hierarchy of Norms in the Juridical, Social and Institutional Order of the Ancient Régime], 21 Revus J. Const. Theory \& Phil. L. 237 (2013) (Fr.).

Di Donato, supra note 51. 
We may imagine that it would not be impossible for courts in the twentyfirst century to make similar attempts. This is precisely what contemporary constitutional courts do when they claim the power to review statutes or even constitutional amendments, by confronting them with some unwritten principles, borrowed from morality or natural law but presented as elements of the legal system. The French Constitutional Council, for example, reviews statutes, that, according to the constitution, are the expression of the general will, i.e. the will of the sovereign. It confronts them not only with the written text of the constitution, but also with some "fundamental principles recognized by the laws of the Republic." These principles are thus supposed not to have been laid down by positive law. They preexisted positive laws and can be identified by the Constitutional Council on the ground that they have been "recognized" in the past by the sovereign, so that they can prevail over the will of the current sovereign.

One might be tempted to draw a parallel between these constitutional courts and international courts, who also can impose on states some unwritten general principles derived from morality, for instance the principle that states are trustees of humanity. There are, however, two important differences.

First, constitutional courts do not acknowledge that they defy or limit the sovereign. On the contrary, they must pretend, just like the Parlements of prerevolutionary France, that they are imposing the will of the sovereign. That is because the constitution that binds the amending power has been willed by the sovereign and the sovereign is supposed to have also willed all the unwritten principles implied by the text, so the court can easily pretend to be applying the will of the sovereign as the author of the original constitution. An international court applying general principles of international law cannot pretend as easily that it is applying the will of the states expressed in unwritten rules of international law.

The second difference is that constitutional courts, even when they confront the constituent power, can always pretend to be the interpreter of the true sovereign. The sovereign who enacted the original constitution may have been dead for centuries, but everything must still be done in its name. A constitutional court decides "in the name of the people," which means that they are on this occasion the true representatives of the people. The logic is the same as that of the Parlements: a conflict between elected bodies and the court can always be interpreted as a conflict between the present people, composed of voters, and an eternal or transcendent people..$^{54}$

54 This theory was first presented in Marcel Gauchet, La Révolution des Pouvoirs. LA SOUVERAINETÉ, LE PEUPLE ET LA REPRÉSENTATION, 1789-1799 [The REVOLUTION 
2015] Sovereignty and Natural Law in the Legal Discourse of the Ancien Régime 335

Such rhetoric would, of course, be much more difficult for an international court. It could obviously treat states as trustees for humanity, but it could not pretend to do so in the name of an international sovereign or even in the name of those same states who are bound by rules regarding international trust.

of Powers. Sovereignty, the People and Representation, 1789-1799] (1995) (Fr.). 
Theoretical Inquiries in Law 16.2 (2015) 